\title{
KEDUDUKAN MAHKAMAH INTERNASIONAL DALAM MENGADILI PERKARA KEJAHATAN KEMANUSIAAN
}

\author{
Rubiyanto*
}

\begin{abstract}
The main matter, a case can be investigated trial by International court of justice is human right violence for instance genocide, war, ethnic killing, human trafficking and salve. No all legal action or law suit could be submitted to International court. Based on the background, could be inferred : How about the existence of International court of justice to take trial human crime? The matter could be conclude that International court of justice one of United Nation organ which have the main task to solve the International dispute, human crime and human right violence in a country.
\end{abstract}

Keyword: The Existence, International Court of Justice, Human Crime.

\section{PENDAHULUAN}

Mahkamah Internasional merupakan lembaga kehakiman Perserikatan BangsaBangsa yang berkedudukan di Den Haag Belanda, lembaga peradilan ini didirikan pada tahun 1945 berdasarkan Piagam Perserikatan Bangsa-Bangsa dan resmi bersidang pada tahun $1946 .{ }^{1}$ Pada dasarnya masalah-masalah yang dapat diperiksa dan diadili oleh Mahkamah Internasional adalah pelanggaran HAM berat, seperti genosida (pemusnahan etnis secara massal), peperangan, pembantaian etnis, perdagangan manusia serta perbudakan. Sesuai lingkup kewenangan tersebut, maka tidak semua persoalan hukum atau sengketa hukum dapat di bawa ke Mahkamah Internasional.

Pada kenyataannya, masyarakat Indonesia saat ini masih banyak yang awam tentang Mahkamah Internasional. Dinamika penegakan hukum di Indonesia,

* Rubiyanto, Dosen Fakultas Hukum UNTAG Semarang dapat dihubungi melalui email : rubiyanto.151161@gmail.com

1 JG Starke, 1992, Introduction To International Law, terj. Bambamg Iriana Djajaatmadja,2008, Pengantar Hukum Internasional, Edisi Kesepuluh, Sinar Grafika. Jakarta, hlm 651 yang menampilkan warna yang berbeda cenderung ke arah abu-abu, telah menimbulkan perbedaan perspektif tentang penegakan hukum di Indonesia. Berbagai persoalan mulai dari persoalan ekonomi, sosial, politik dan pemerintahan yang berujung pada persoalan hukum, tampak mendominasi media massa baik cetak maupun elektronik. Kekecewaan sebagian masyarakat atas upaya penegakan hukum (law enforcement) menyebabkan muncul nya tuntutan atas upaya penegakan hukum yang melibatkan instrumen peradilan internasional (Mahkamah Internasional). Hal tersebut dapat terjadi karena sistem penegakan hukum dianggap tidak mampu menjawab tantangan dan kebutuhan dalam masyarakat serta dianggap tidak mampu mewujudkan rasa keadilan.

Keinginan seseorang atau sekelompok orang membawa persoalan hukum dalam negeri ke Mahkamah Internasional, di satu sisi dapat dipahami sebagai adanya satu kesadaran hukum, namun di sisi lain menunjukkan ketidak pahaman masyarakat tentang status dan kedudukan Mahkamah Internasional sebagai lembaga peradilan internasional. Salah satu contoh misalnya ancaman dari 
penasehat hukum mantan ketua DPR Setya Novanto, yang akan mengadukan KPK ke Pengadilan HAM Internasional karena menahan setya Novanto yang masih sakit. ${ }^{2}$

Berdasarkan kenyataan tersebut, penulis tertarik untuk mengkaji lebih mendalam mengenai ruang lingkup kompetensi Mahkamah Internasional dalam menangani perkara-perkara internasional sesuai Piagam PBB dikaitkan dengan perkara-perkara dalam kategori kejahatan kemanusiaan dalam negeri.

\section{PERUMUSAN MASALAH}

Berdasarkan uraian pada pendahulu an diatas, dapat dirumuskan suatu permasalahan sebagai berikut: Bagaimana kedudukan Mahkamah Internasional dalam mengadili perkara kejahatan kemanusiaan?

\section{PEMBAHASAN}

\section{Pengertian Kejahatan Kemanusiaan}

Sebelum dibahas mengenai pengerti an kejahatan kemanusiaan, terlebih dahulu perlu dipahami sejarah munculnya kejahatan kemanusiaan. Kejahatan terhadap kemanusiaan muncul pertama kali pada tahun 1915 untuk menggambarkan suatu kejahatan luar biasa berupa pembunuhan besar-besaran di Kerajaan Ottoman. Pada saat itu muncul permasalah an yuridis berhubungan dengan berlakunya asas non-retroaktif dalam hukum pidana dimana asas tersebut tidak memungkinkan mengadili suatu tindak pidana yang mana tindak pidana tersebut belum ada hukum yang mengatur. ${ }^{3}$

Tanggal 28 Mei 1915 pemerintah Perancis, Inggris, dan Rusia memutuskan untuk melakukan deklarasi terkait kasus pembunuhan massal terhadap orang-orang

2 www.tribuinnewes,com Pengacara Setya Novanto ingin Lakporkan KPK ke Pengadilan HAM Internasional, diakses tanggal 10 Maret 2018

3 I Made Pasek Diantha, 2014, Hukum Pidana Internasional Dalam Dinamika Pengadilan Pidana Internasional, Prenadamedia Group, Jakarta, hlm. 165
Armenia di Kerajaan Ottoman. Deklarasi bersama tiga negara tersebut melahirkan istilah kejahatan terhadap kemanusiaan, namun istilah tersebut hanya mendapatkan perhatian jangka pendek dalam menyelesai kan permasalahan politik, Hal ini terlihat setelah deklarasi tersebut yang tidak ada upaya yang kongkret dari deklarasi bersama tersebut. ${ }^{4}$

Pada tahun 1945 perdebatan mengenai pemberlakuan asas retroaktif kembali terjadi ketika dilakukannya pembahasan mengenai rancangan Statuta Pengadilan Nuremberg yang kemudian perdebatan tersebut diakhiri dengan penerimaan asas retroaktif dalam pemberlakuannya yurisdiksi material. $^{5}$

Pengertian kejahatan kemanusiaan dapat dilihat pada Piagam Tribunal Militer Internasional, Nuremberg Pasal 6 (c) yang memberikan penjelasan mengenai kejahatan terhadap kemanusiaan sebagai berikut:

"Pembunuhan, pemusnahan, per budakan, pemindahan secara paksa dan tindakan tidak manusiawi lainnya yang ditujukan pada masyarakat sipil, sebelum atau selama perang, atau penindasan berdasarkan politik, ras atau agama dalam pelaksanaan atau dalam ruang lingkup pengadilan ini, apakah perbuatan tersebut baik yang melanggar atau tidak hukum dimana perbuatan tersebut dilakukan".

Pengertian kejahatan kemanusiaan juga dapat ditemukan dalam Pasal 5 huruf c International Military Tribunal for the Far East (IMTFE) atau dikenal dengan Tokyo Tribunal yang menyatakan bahwa:

4 Tolib Effendi, 2014, Hukum Pidana Internasional, Pustaka Yustisia, Yogyakarta, hlm. 100

5 William A. Schabas, 2011, An Introduction to International Criminal Court, dalam I Made Pasek Diantha, 2014, Hukum Pidana Internasional Dalam Dinamika Pengadilan Pidana Internasional, Prenadamedia Group, Jakarta, h. 165

6 Anis Widyawati, 2014, Hukum Pidana Internasional, Sinar Grafika, Jakarta Timur, hlm. 93 
"Yang termasuk kejahatan terhadap kemanusiaan adalah pembunuhan, pemusnahan, perbudakan, deportasi dan tindakan tidak manusiawi lainnya yang dilakukan terhadap populasi sipil manapun, sebelum dan selama masa perang, atau penindasan berdasarkan politik, ras, sebagai bagian atau dilakukan sehubungan dengan bentuk kejahatan lainnya yang masuk dalam yurisdiksi pengadilan, baik tindakan tersebut dianggap sebagai kejahatan atau tidak."

Kejahatan terhadap kemanusiaan dalam Konvensi tentang Ketidakberlakuan Pembatasan Aturan Hukum untuk Kejahatan Perang dan Kejahatan Terhadap Kemanusiaan, Resolusi Majelis Umum PBB 2392 (XXIII), 26 November 1968, tercantum dalam Pasal 1 (b) yang mengatakan bahwa:

"Kejahatan-kejahatan kemanusiaan yang dilakukan dalam waktu perang maupun dalam waktu damai seperti yang didefinisikan dalam Piagam Tribunal Militer Internasional, Nuremberg, 8 Agustus 1945 dan yang dikuatkan dengan resolusi-resolusi Majelis Umum PBB, 3 (1) 13 Februari 1946 dan 95 (1) 11 Desember 1946, pengusiran dengan bersenjata, atau pendudukan dan apartheid dan kejahatan genosida, seperti didefinisikan dalam Konvensi 1948 tentang Pencegahan dan Penghukuman terhadap Kejahatan Genosida, sekalipun perbuatan-perbuatan tersebut tidak merupakan kejahatan terhadap hukum domestik dari negara tempat kejahatan-kejahatan dilakukan".

Kejahatan terhadap Kemanusiaan juga diatur dalam statuta lainnya yaitu, ICTY (International Criminal Tribunal for Former Yugoslavia), ICTR (International Criminal Tribunal for Rwanda) dan Statuta Roma 1998. Pasal 5 Statuta ICTY, tentang

7 Ibid. 93

8 Eddy Omar Sharif Hiariej, 2009, Pengantar Hukum Pidana Internasional, Erlangga, Jakarta, hlm. 38
Kejahatan terhadap Kemanusiaan mengatakan bahwa:

"Pengadilan Internasional memiliki kemampuan untuk menuntut setiap orang yang bertanggung jawab atas kejahatan berikut ini yang dilakukan selamakonflik bersenjata berlangsung, yang bersifat internasional maupun internal dan ditujukan langsung terhadap penduduk sipil:

a. Pembunuhan;

b. Pemusnahan;

c. Perbudakan;

d. Pendeportasian;

e. Penahanan;

f. Penyiksaan;

g. Pemerkosaan;

h. Penindasan berdasarkan politik, ras dan agama;

i. Tindakan tidak manusiawi lainnya. ${ }^{9}$

Pengaturan paling lengkap mengenai kejahatan terhadap kemanusiaan terdapat dalam Pasal 7 Statuta Roma 1998. Secara substantif isi dari statuta ini hampir sama dengan dua statuta sebelumnya, namun dalam Statuta ini pengaturan mengenai Kejahatan terhadap Kemanusia an lebih diperjelas dan lengkap. Pasal 7 ayat (1) Statuta Roma 1998 mengatur mengenai jenis-jenis perbuatan yang termasuk dalam kualifikasi Kejahatan terhadap Kemanusia an sebagai berikut:

a. Serangan terhadap penduduk sipil

b. Pemusnahan

c. Perbudakan

d. Pengusiran atau pemindahan penduduk secara paksa

e. Penyiksaan

f. Penghamilan paksa

g. Penindasan

h. Kejahatan apartheid

i. Penghilangan orang secara paksa. ${ }^{10}$

Selanjutnya dalam ketentuan Pasal 7 ayat (2), Statuta Roma 1998 dijelaskan

9 Tolib Effendi, Op.Cit., , hlm. 102

10 Ibid., , hlm. 104 
sebagai berikut:

a. Serangan yang terdiri dari tindakan sebagaimana disebutkan dalam ayat (1) terhadap penduduk sipil yang berkaitan dengan atau merupakan tindak lanjut dari kebijakan negara atau organisasi untuk melakukan penyerang an tersebut.

b. Pemusnahan diartikan sebagai tindakan yang termasuk di antaranya penerapan kondisi tertentu yang mengancam kehidupan secara sengaja, antara lain menghambat akses terhadap makanan dan obat-obatan, yang diperkirakan dapat menghancurkan sebagian penduduk;

c. Perbudakan diartikan sebagai segala bentuk pelaksanaan hak milik terhadap objek yang berupa orang, termasuk tindakan mengangkut objek tersebut, khususnya perempuan dan anak-anak;

d. Pengusiran atau pemindahan penduduk secara paksa diartikan sebagai tindakan merelokasi penduduk melalui pengusir an atau cara kekerasan lainnya dari tempat dimana penduduk tersebut secara sah berada, tanpa dasar yang dibenarkan menurut hukum inter nasional;

e. Penyiksaan diartikan tindakan secara sengaja untuk memberikan rasa sakit atau penderitaan, baik fisik maupun mental, orang-orang yang ditahan dibawah kekuasaan pelaku. Kecuali itu, bahwa penyiksaan tersebut tidak termasuk rasa sakit atau penderitaan yang hanya muncul secara inheren atau incidental dari pengenaan sanksi yang sah;

f. Penghamilan paksa berarti penyekapan secara tidak sah seorang perempuan yang dibuat hamil secara paksa, dengan maksud memengaruhi komposisi etnis suatu populasi atau merupakan pelanggaran berat lainnya terhadap hukum internasional. Definisi ini tidak dapat ditafsirkan mempengaruhi hukum nasional terkait kehamilan;

g. Penindasan diartikan penyangkalan keras dan sengaja terhadap hak-hak dasar dengan cara bertentangan dengan hukum internasional dengan alasan identitas sebuah kelompok atau kolektif;

h. Kejahatan apartheid diartikan tindakan tidak manusiawi dengan karakter yang serupa dengan tindakan-tindakan yang disebutkan dalam ayat (1), dilakukan dalam konteks penindasan sistematis yang dilakukan oleh suatu rezim dan dominasi satu kelompok ras tertentu dari kelompok ras lainnya dengan maksud untuk mempertahankan rezim tesebut

i. Penghilangan orang secara paksa diartikan sebagai penangkapan, penahanan atau penculikan terhadap seseorang atas dasar wewenang, dukungan atau persetujuan suatu negara ataupun organisasi politik, yang kemudian diikuti oleh penolakan pengakuan kebebasan atau pemberian informasi tentang keberadaan orangorang tersebut, dengan maksud untuk menghilangkan perlindungan hukum dalam waktu yang lama. ${ }^{11}$

Berdasarkan pengertian di atas, dapat diketahui bahwa suatu kejahatan kemanusiaan adalah kejahatan yang dilakukan oleh setiap orang atas kejahatan yang dilakukan selama konflik bersenjata berlangsung, yang bersifat internasional maupun internal dan ditujukan langsung terhadap penduduk sipil yang meliputi Serangan terhadap penduduk sipil, Pemusnahan, Perbudakan, Pengusiran atau pemindahan penduduk secara paksa, Penyiksaan, Penghamilan paksa, Penindasan, Kejahatan apartheid dan Penghilangan orang secara paksa.

$11 \mathrm{Ibid}$, , hlm. 104 
2. Kedudukan Mahkamah Inter nasional (International Court of Justice) dalam Mengadili Perkara Kejahatan Kemanusiaan

Mahkamah Internasional (Inter national Court Of Justice) adalah lembaga kehakiman Perserikatan Bangsa-Bangsa yang berkedudukan di Den Haag Belanda, lembaga peradilan ini didirikan pada tahun 1945 berdasarkan Piagam Perserikatan Bangsa-Bangsa dan resmi bersidang pada tahun $1946 .{ }^{12}$

Mahkamah Internasional (International Court Of Justice) dibentuk berdasarkan Bab IV Pasal 92-96 Piagam Perserikatan Bangsa-Bangsa yang dirumuskan di San Fransisco. Disebutkan dalam ketentuan Pasal 92 bahwa Mahkamah Internasional (International Court Of Justice) adalah organ utama dari Perserikatan Bangsa-Bangsa. Pasal 92 Piagam Perserikatan Bangsa-Bangsa secara lengkap sebagai berikut;

"The International Court of Justice shall be the principal judicial organ of The United Nations. It shall function in accordance with the annexed Statute, which is base upon the Statute of The Permanent Court of Justice and form an integral part of the present Charter

(Mahkamah Agung Internasional adalah badan peradilan utama dari Perserikatan Bangsa-Bangsa Badan ini akan bekerja sesuai dengan Statuta Mahkamah Tetap Internasional dan peradilan merupakan bagian yang tidak terpisah dari Piagam ini.

Berdasarkan ketentuan tersebut, terdapat 3 (tiga) hal yang diatur, yaitu:

a. Mahkamah Internasional (International Court Of Justice) adalah merupakan bagian yang integral dalam sistem PBB. Hal ini tidak ada pada Permanent Court

12 JG Starke, 1992, Introduction To International Law, terj. Bambamg Iriana Djajaatmadja,2008, Pengantar Hukum Internasional, Edisi Kesepuluh, Sinar Grafika. Jakarta, hlm 651
Of Justice dalam rangka Liga BangsaBangsa. Mahkamah Internasional (International Court Of Justice) sebagai organ utama PBB sangat dekat dengan tujuan dari PBB. Hal tersebut mengandung pengertian bahwa Mahkamah Internasional (International Court Of Justice) sebagai organ utama PBB menunjukkan penyelesaian sengketa melalui pengadilan sebagai suatu komponen penting dalam mekanisme perdamaian internasional. Hal yang penting adalah adanya integrasi dan koordinasi antara dua subjek yang berbeda diletakkan di bawah suatu instrument internasional tunggal yaitu Piagam Perserikatan Bangsa-Bangsa. Konsekuensi logis dari hubungan khusus ini adalah bahwa Mahkamah Internasional (International Court Of Justice) terikat untuk mengadakan kerja sama dengan organorgan PBB dan Statuta Mahkamah Internasional. Mahkamah Internasional (International Court Of Justice) sebagai organ utama PBB, pelaksanaan tugasnya sejalan dengan tujuan PBB yang ditentukan dalam Piagam. Status Mahkamah Internasional (International Court Of Justice) sebagai organ utama PBB menentukan tanggung jawabnya dan kesamaan derajad dengan organ utama lainnya sesuai dengan kewenangannya

b. Semua anggota PBB ipso facto menjadi pihak Mahkamah Internasional (International Court OfJustice).

c. Dalam hal pelaksanaan keputusan berdasarkan Pasal 94 (1) Piagam PBB bahwa setiap anggota PBB mematuhi keputusan Mahkamah Internasional (International Court Of Justice) dalam perkara apapun dimana anggota tersebut menjadi salah satu pihak, sedangkan Pasal 94 ayat (2) menyatakan apabila suatu pihak dalam perkara tidak 
memenuhi kewajiban yang dibebankan kepadanya oleh suatu keputusan Mahkamah Internasional (International Court Of Justice), pihak yang lain dapat meminta perhatian Dewan Keamanan, jika perlu dapat memberikan rekomendasi atau menentukan tindakan yang akan diambil untuk terlaksananya keputusan itu.

Tugas utama dari Mahkamah Internasional (International Court Of Justice) adalah untuk menyelesaikan sengketa-sengketa internasional mencakup bukan saja sengketa-sengketa antar Negara saja, melainkan juga kasus-kasus lain yang berada dalam lingkup pengaturan internasional, yakni beberapa katagori sengketa tertentu antara Negara di satu pihak dan individu-individu, badan-badan korporasi serta badan-badan bukan Negara di pihak lain.

Mahkamah Internasional (Inter national Court Of Justice) memiliki kedudukan khusus dibandingkan lima organ utama Perserikatan Bangsa-Bangsa lainnya. Mahkamah Internasional (International Court Of Justice), dijalankan oleh 15 orang hakim dan 2 orang merangkap sebagai ketua dan wakil ketua. Mahkamah Internasional (International Court Of Justice), dibentuk berdasarkan Bab IV Pasal 92-96 Piagam Perserikatan Bangsa-Bangsa.

Mahkamah Internasional (Inter national Court of Justice), dalam menyelesaikan sengketa hendaknya dengan cara yang seadil-adilnya bagi para pihak, hal ini merupakan tujuan dari dibentuknya Hukum Internasional. Sedangkan kaidah dan prosedur yang dipergunakan sebagian merupakan kebiasaan dan praktek, serta sejumlah konvensi yang penting seperti Konvensi The Haque Tahun 1899 dan 1907 untuk penyelesaian sengketa secara damai dan Piagam Perserikatan Bangsa-Bangsa.

Menurut Sri Setyaningsih Suwardi, Mahkamah Internasional (International
Court Of Justice) sebagai organ utama PBB mempunyai tugas utama sebagai berikut: ${ }^{13}$

a. Memutuskan perkara antar Negara baik antar Negara anggota PBB maupun bukan anggota PBB

b. Memberikan pedoman dan mensupport kerja dari organ utama PBB lainnya dan untuk Badan khusus melalui pendapat hukum- nya (advisory opinion)

c. Terlibat dalam kegiatan extrajudicial Berkaitan dengan pihak yang dapat mengajukan perkaranya kepada Mahkamah Internasional (International Court Of Justice) adalah :

a. Negara anggota Perserikatan BangsaBangsa secara otomatis dapat mengajukan sengketanya kepada Mahkamah Internasional (Inter national Court Of Justice),

b. Negara bukan anggota Perserikatan Bangsa-Bangsa dapat mengajukan sengketa kepada Mahkamah Inter nasional (International Court Of Justice), yang menjadi wilayah kerja dari Mahkamah Internasional (International Court Of Justice), tersebut.

c. Negara bukan anggota Perserikatan Bangsa-Bangsa dapat mengajukan sengketa kepada Mahkamah Internasional (International Court Of Justice), yang bukan menjadi wilayah kerja dari Mahkamah Internasional (International Court Of Justice), dengan syarat membuat Deklarasi untuk tunduk pada ketentuan Mahkamah Inter nasional (International Court of Justice), dan Piagam PBB. ${ }^{14}$

Berkaitan dengan wewenang mengenai jenis sengketa yang dapat diajukan, menurut Pasal 36 (1) Statuta Mahkamah Internasional (International

13 Sri Setyaningsih Suwardi, 2006, Penyelesaian Sengketa Internasional, Cet. Pertama, UI Press, Jakarta, hlm 61

14 Huala Adolf, 2008, Penyelesaian Sengketa Internasional, Sinar Grafika, Bandung, hlm 35 
Court Of Justice), dinyatakan bahwa :

Wewenang Mahkamah meliputi semua perkara yang diajukan pihakpihak yang bersengketa kepadanya, terutama yang terdapat dalam Piagam PBB atau dalam perjanjian-perjanjian dan konvensi-konvensi yang berlaku.

Kewenangan yang dimiliki Mahkamah Internasional (International Court Of Justice) adalah bersifat Fakultatif yaitu bahwa bila terjadi suatu sengketa antara dua negara, intervensi Mahkamah Internasional (International Court Of Justice), baru dapat terjadi bila negaranegara yang bersengketa dengan persetujuan bersama membawa perkara itu ke Mahkamah Internasional (International Court Of Justice). Tanpa adanya persetujuan dari pihak-pihak yang bersengketa, wewenang Mahkamah Internasional (International Court of Justice) tidak akan berlaku terhadap sengketa tersebut. Menurut Pasal 36 ayat (2) Statuta Mahkamah Internasional (International Court Of Justice) maka negara-negara yang menyetujui Statuta Mahkamah Internasional (International Court Of Justice) dapat menyatakan setiap waktu bahwa mereka dengan sendirinya akan tunduk kepada keputusan-keputusan Mahkamah Internasional (International Court Of Justice). Keputusan-keputusan yang dimaksud tersebut dapat mengenai persengketaan tentang:

a. Penafsiran perjanjian

b. Soal-soal yang hukum internasional

c. Adanya suatu hal yang mengakibatkan pelanggaran perjanjian internasional yang dilakukan oleh salah satu pihak.

d. Jenis/besarnya ganti rugi yang akan dibayar berhubungan dengan pelanggar an suatu kewajiban perjanjian inter nasional

Mahkamah Internasional (Inter national Court Of Justice), selain memiliki kewenangan, juga memiliki yurisdiksi dalam menyelesaikan sengketa antar Negara. Yurisdiksi Mahkamah Inter nasional (International Court Of Justice) terdiri dari :

a. Memutuskan Perkara-perkara Pertikaian

Untuk yurisdiksi pertikaian dalam kasus-kasus pertikaian pelaksanaan yurisdiksi mahkamah menyarankan adanya persetujuan para pihak yang bersengketa. Pada Pasal 36 ayat (1) Statuta Mahkamah Internasional (International Court of Justice) yang menyatakan bahwa Mahkamah Internasional (International Court Of Justice) memiliki yurisdiksi terhadap semua perkara yang diajukan oleh para pihak. Untuk pengajuan tersebut biasanya dilakukan dengan memberitahu kan suatu perjanjian bilateral yang dinamakan compromise. Suatu penyerahan sepihak dari sengketa kepada Mahkamah Internasional (International Court Of Justice) oleh salah satu pihak telah dianggap mencukupi apabila pihak atau pihak-pihak yang lain dalam sengketa tersebut menyetujui penyerahan demikian atau kemudian menyetujui.

b. Memberikan Opini-opini/Nasihat

Mahkamah Internasional (Inter national Court of Justice) dapat memberikan opini/nasihat kepada Negaranegara yang meminta, selain itu Mahkamah Internasional (International Court Of Justice) juga dapat memberikan opini/ nasihat yang diminta oleh Majelis Umum dan Dewan Keamanan PBB, serta badanbadan lain dari PBB selama diijinkan oleh Majelis Umum. Opini-opini atau nasihat yang diberikan oleh meliputi persoalanpersoalan hukum yang timbul dalam lingkup aktifitas mereka. Prosedur permintaan opini / nasihat kepada Mahkamah Internasional (International Court Of Justice) harus disampaikan secara tertulis yang berisi suatu pernyataan tentang persoalan-persoalan yang akan 
dimintakan opini/ nasihat kepada Mahkamah Internasional (International Court Of Justice) disertai dengan dokumendokumen yang menunjang PBB yang diserahkan kepada Mahkamah Inter nasional(International Court Of Justice).

Yurisdiksi yang dimiliki Mahkamah Internasional (International Court Of Justice) pada Pasal 36 Statuta tersebut, menurut L.Oppenheim dapat dibedakan antara:

a. Jurisdiksi sukarela (voluntary) Kewenangan sukarela ini dimaksud kan bahwa kewenangan Mahkamah Internasional (International Court Of Justice) tergantung pada persetujuan negara negara yang bersengketa. Mahkamah Internasional (International Court Of Justice) tidak mempunyai yurisdiksi memberikan keputusan kecuali pihak yang bersengketa memberikan persetujuannya. b. Jurisdiksi wajib (obligatory).

Para pihak terikat dengan apa yang dikenal dengan option clausule yang diatur pada Pasal 36 ayat (2) yang menggambarkan penerimaan suatu Nega- ra atas penyelesaian yudisial terten tu, dan apabila kedua belak pihak telah membuat deklarasi atas sengketa mereka, berarti telah ditetapkan yurisdiksi dari International Court Of Justice ${ }^{15}$

Mahkamah Internasional (Inter national Court Of Justice) mempunyai tambahan yurisdiksinya, yaitu melaksana kan yurisdiksi lebih lanjut yaitu yurisdiksi insidental dimana Mahkamah Internasional (International Court Of Justice) mempunyai wewenang interalia untuk menunjukkan tindakan proteksi sementara, memperbolehkan intervensi pihak ketiga dalam suatu kasus dan mengintepretasikan keputusan sebelumnya. Karena kewenang an ini diberikan oleh Statuta Mahkamah Internasional (International Court Of

15 J.G. Merrilis, 1986. Penyelesaian Sengketa Internasional, penyadur Achmad Fauzan, Tarsito, Bandung, hlm 97
Justice), maka pelaksanaannya tidak tergantung pada persetujuan negara-negara.

Berdasarkan Pasal 59 Statuta Mahkamah Internasional (International Court Of Justice), Mahkamah Internasional (International Court Of Justice) hanya mempunyai kekuatan mengikat terhadap pihak-pihak dan hanya berhubungan dengan perkara khusus tersebut. Menurut Mochtar Kusumaatmaja, walaupun keputus an pengadilan tidak mempunyai kekuatan mengikat, keputusan pengadilan inter nasional terutama Mahkamah Internasional (International Court Of Justice) mem punyai pengaruh yang besar dalam perkembangan hukum internasional. ${ }^{16}$

Merujuk pada kewenangan Mahkamah Internasional (International Court Of Justice) tersebut di atas, tugas Mahkamah Internasional (International Court Of Justice) adalah menyelesaikan sengketa-sengketa internasional mencakup bukan saja sengketa-sengketa antar Negara saja, melainkan juga kasus-kasus lain yang berada dalam lingkup pengaturan internasional, yakni beberapa katagori sengketa tertentu antara Negara di satu pihak dan individu-individu, badan-badan korporasi serta badan-badan bukan Negara di pihak lain.

Berdasarkan uraian di atas, dapat dipahami bahwa kedudukan Mahkamah Internasional (International Court Of Justice) sebagai salah satu organ penting Persatuan Bangsa-Bangsa yang tugas utama dari Mahkamah Internasional (International Court Of Justice) adalah untuk menyelesaikan sengketa-sengketa internasional mencakup bukan saja sengketa-sengketa antar Negara saja, melainkan juga kasus-kasus lain yang berada dalam lingkup pengaturan inter nasional, yakni beberapa katagori sengketa tertentu antara Negara di satu pihak dan

16 Mochtar Kusumaatmaja dan Etty Agoes,2003, Pengantar Hu kum Internasional, PT. Alumni, Bandung, hlm 69-72 
individu-individu, badan-badan korporasi serta badan-badan bukan Negara di pihak lain.

Mahkamah Internasional (Inter national Court Of Justice) juga dapat berkerdudukan sebagai Mahkamah Pidana Internasional (International Criminal Court Of Justice) dalam penanganan perkara-perkara kejahatan kemanusiaan di suatu negara ataupun pelanggaran HAM berat.

\section{KESIMPULAN}

Berdasarkan pembahasan sebagai mana tersebut di atas, dapat disimpulkan bahwa Mahkamah Internasional (Inter national Court Of Justice) adalah salah satu organ penting Persatuan Bangsa-Bangsa yang tugas utamanya menyelesai kan sengketa-sengketa internasional, serta penanganan perkara-perkara kejahatan kemanusiaan di suatu negara ataupun pelanggaran HAM berat.

\section{SARAN}

Mahkamah Internasional (Inter national Court Of Justice) memiliki kedudukan khusus dengan jurisdiksi terbatas, sehingga tidak setiap perkara dapat diajukan ke Mahkamah Internasional (International Court Of Justice). Masyarakat perlu memahami kedudukan Mahkamah Internasional (International Court Of Justice) agar tidak salah dalam mempersepsikan lembaga pengadilan internasional tersebut.

\section{DAFTAR PUSTAKA}

Anis Widyawati, 2014, Hukum Pidana Internasional, Sinar Grafika, Jakarta Timur

Eddy Omar Sharif Hiariej, 2009, Pengantar Hukum Pidana Internasional,
Erlangga, Jakarta,

Huala Adolf, 2008, Penyelesaian Sengketa Internasional, Sinar Grafika, Bandung,

I Made Pasek Diantha, 2014, Hukum Pidana Internasional Dalam Dinamika Pengadilan Pidana Internasional, Prenadamedia Group, Jakarta

J.G. Merrilis, 1986. Penyelesaian Sengketa Internasional, penyadur Achmad Fauzan, Tarsito, Bandung

JG Starke, 1992, Introduction To International Law, terj. Bambamg Iriana Djajaatmadja, 2008 , Pengantar Hukum Internasional, Edisi Kesepuluh, Sinar Grafika. Jakarta

Mochtar Kusumaatmaja dan Etty Agoes, 2003, Pengantar Hukum Inter nasional, PT. Alumni, Bandung

Sri Setyaningsih Suwardi, 2006, Penyelesaian Sengketa Inter nasional, Cet. Pertama, UI Press, Jakarta

Tolib Effendi, 2014, Hukum Pidana Internasional, Pustaka Yustisia, Yogyakarta,

William A. Schabas, 2011, An Introduction to International Criminal Court, dalam I Made Pasek Diantha, 2014, Hukum Pidana Internasional Dalam Dinamika Pengadilan Pidana Internasional, Prenada media Group, Jakarta

Piagam Perserikatan Bangsa-Bangsa

Resolusi Majelis Umum PBB 2392 (XXIII), 26 November 1968

International Military Tribunal for the Far East (IMTFE)/Tokyo Tribunal

Statuta Roma 1998

www.tribuinnewes,com Pengacara Setya Novanto ingin Lakporkan KPK ke Pengadilan HAM Internasional, diakses tanggal 10 Maret 2018 